\title{
Genome of non-living cells: trash or recycle?
}

\author{
Pasqualino Loi, Josef Fulka Jr${ }^{1}$, Thomas Hildebrand ${ }^{2}$ and Grazyna Ptak \\ Department of Comparative Biomedical Sciences, University of Teramo, Piazza Aldo Moro 45, 64100 Teramo, Italy, \\ ${ }^{1}$ Institute of Animal Science, 10400 Prague, Czech Republic and ${ }^{2}$ Institute für Zoo und Wildtierforschung (IZW), \\ 601103 Berlin, Germany
}

Correspondence should be addressed to P Loi; Email: ploi@unite.it

\begin{abstract}
Reproductive technologies have been often used as a tool in research not strictly connected with developmental biology. In this study, we retrace the experimental routes that have led to the adoption of two reproductive technologies, ICSI and somatic cell nuclear transfer (SCNT), as biological assays to probe the 'functionality' of the genome from dead cells. The structural peculiarities of the spermatozoa nucleus, namely its lower water content and its compact chromatin structure, have made it the preferred cell for these experiments. The studies, primarily focused on mice, have demonstrated an unexpected stability of the spermatozoa nuclei, which retained the capacity to form pronuclei once injected into the oocytes even after severe denaturing agents like acid treatment and high-temperature exposure. These findings inspired further research culminating in the production of mice after ICSI of lyophilized spermatozoa. The demonstrated non-equivalence between cell vitality and nuclear vitality in spermatozoa prompted analogous studies on somatic cells. Somatic cells were treated with the same physical stress applied to spermatozoa and were injected into enucleated sheep oocytes. Despite the presumptive fragile nuclear structure, nuclei from non-viable cells (heat treated) directed early and post-implantation embryonic development on nuclear transfer, resulting in normal offspring. Recently, lyophilized somatic cells used for nuclear transfer have developed into normal embryos. In summary, ICSI and SCNT have been useful tools to prove that alternative strategies for storing banks of non-viable cells are realistic. Finally, the potential application of freeze-dried spermatozoa and cells is also discussed.

Reproduction (2011) 142 497-503
\end{abstract}

\section{Introduction}

DNA may be particularly stable under certain conditions. The plant kingdom offers some examples of long-term DNA stability, particularly in seeds. A recent work demonstrated that 2000-year-old date palm (Phoenix dactylifera L.) seeds found in Israel were able to germinate and develop into a normal palm tree (Sallon et al. 2008).

Seeds acquire the capacity to withstand long periods of quiescence at the end of a developmentally regulated maturation phase that leads to the loss of bulk water from the entire structure. The desiccation tolerance of the seeds has to be primarily ascribed to the progressive accumulation of proteins and sugars which exert their protective function by stabilizing lipids and structural proteins (Hand et al. 2010).

Nothing comparable in terms of chromatin organization and stability has been described in the animal kingdom. However, molecules - primarily DNA and more recently proteins (Asara et al. 2007) - extracted from fossils can be collected and show a good degree of preservation. Indeed, DNA collected from bones of extinct wild animals, like cave bears, wolves, and horses, has been successfully used as a template to amplify short sequences that were then sequenced (Hoelzel 2005). The development of high-throughput parallel sequencing technologies has given a major impulse to the study of ancient DNA, and full sequences from Neanderthal (Green et al. 2008) and Thylacinus cynocephalus (Miller et al. 2009) mtDNA are now available, while the mammoth genome has already been sequenced (Miller et al. 2008). These data cast some light on the phylogenetic relationships between extinct and existing animal populations and provide unique elements to understand the genetic contribution of Neanderthals to modern humans (Endicott et al. 2010).

Besides phylogenetic studies, DNA sequences from extinct species are also used to verify whether gene functions have evolved. Particularly interesting in this regard are studies on the melanocortin 1 receptor $(M C 1 R)$, the gene responsible for melanic polymorphisms, which have been conducted in the mammoth (Römpler et al. 2006) and Neanderthals (Lalueza-Fox et al. 2007). The function of the MC1R gene product was assessed in vitro using cell lines transfected with the 
plasmid constructed from the sequences amplified from ancient DNA. In another interesting functional study, the activity of the genome of an extinct marsupial, the Tasmanian tiger (T. cynocephalus), was tested by a transgenic approach in which a portion of its genome was brought back to life after 100 years of storage in alcohol (Pask et al. 2008). Specifically, the transcriptional enhancer element of the pro- $\alpha 1$ (II) collagen (Col2a1) gene was isolated from the DNA extracted from 100year-old thylacine specimens. A construct containing the Col2a1 sequence flanked by the human $\beta$-globin basal promoter carrying a lacZ sequence was injected into mouse zygotes (Pask et al. 2008). Whole mount and histological sections of the transgenic fetuses have demonstrated the expression of the gene construct in the chondrocytes of the developing limbs. Although only a minimal fraction of the T. cynocephalus genome was analyzed, the results of this experiment are very exciting and bring forward the question of whether the whole genome of extinct species might be still functional.

\section{Reproductive technologies as tools to test the functionality of genomes from extinct/dead animals and from non-viable (dead) cells: I - ICSI}

Reproductive biotechnologies represent a unique, perhaps the only, approach to assess the functionality of genomes from extinct organisms or non-viable (dead) cells.

Assessing the functionality of nuclei of dead cells is a complex task, given that nothing comparable to seeds in terms of DNA conformation and stability exists in animal cells, although some similarities might be found in spermatozoa: 'the mammalian seeds'. During postmeiotic maturation, spermatids undergo global remodeling of their nucleus, which elongates, loses two-thirds of its water (a process reminiscent of seed maturation), and compacts into the typical nuclear structure of spermatozoa (Ward \& Zalensky 1996, Rousseaux et al. 2005). Not surprisingly, then, the first attempts to explore the 'functionality' of genomes of non-viable cells were conducted using spermatozoa.

Mature spermatozoa may be considered a sort of 'resistance' cell, since they might be able to fertilize an egg after having spent several days in the female reproductive tract. Moreover, their potential to participate in embryogenesis is not lost when the sperm cells die. The first report about using non-viable spermatozoa for fertilization was published by Goto et al. (1990). In that study, bull spermatozoa were deliberately killed by several cycles of freezing and thawing without cryoprotection and then injected into metaphase II oocytes. Although only few of the injected oocytes developed into blastocysts $(8 \%)$, two normal calves were born following transfer of such embryos into recipient cows. In a more recent work, testicular spermatozoa retrieved from male mice (BALB/C nude and $\mathrm{C} 3 \mathrm{H} / \mathrm{He}$ strains) that were stored in mechanical freezers $\left(-15^{\circ} \mathrm{C}\right)$ for 15 years were able to produce normal offspring after ICSI, confirming the nuclear stability of spermatozoa (Fig. 1; Ogonuki et al. 2006).

The stability of the mammalian spermatozoon nucleus was thoroughly investigated by Yanagimachi's group, who demonstrated that the ability to form pronuclei is not lost after different physical or chemical treatments, such as exposure to $90{ }^{\circ} \mathrm{C}$ for $30 \mathrm{~min}, 20$ days in $100 \%$ ethanol or Carnoy's fixative, or freeze-drying (i.e. lyophilization; Katayose et al. 1992, Yanagimachi 1994). A few years later, the same group announced the birth of normal pups by injecting lyophilized spermatozoa, which were stored for 6 months and transported from Japan to Hawaii, into mouse eggs (Wakayama \& Yanagimachi 1998).

The mechanical and osmotic stress due to freezing and drying damages the spermatozoon membrane (including the acrosome), resulting in cell death and motility loss. However, the lack of motility is no longer an obstacle to fertilization, since the microinjection of spermatozoa into oocytes is now routinely performed in many embryological laboratories. Moreover, the acrosomal loss might turn out to be a positive factor, since it appears that its presence exerts a negative effect on ICSI outcome (Morozumi et al. 2005, Morozumi \& Yanagimachi 2006). Conversely, the nuclear compartment of lyophilized spermatozoa is not affected by freeze-drying and re-hydration, as indicated by the observation that chromosomal abnormalities of blastocyst-stage embryos derived from freeze-dried sperm are comparable to those of mouse embryos obtained using fresh sperm (Kusakabe et al. 2001, 2008). Since the first reports, many laboratories are working toward the optimization of protocols for freeze-drying spermatozoa (Kaneko et al. 2003a, 2003b).
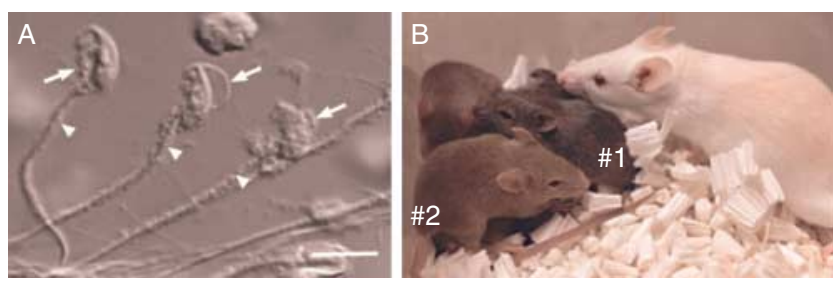

Figure 1 Production of mice using spermatozoa retrieved from testes of male mice that were stored frozen for 15 years. (A) Spermatozoa collected from seminiferous tubules show severe structural damage. The head (arrows) and midpiece (arrowheads) have cellular debris. (B) Pups were born after injection of frozen spermatozoa (BALB/c nude) into B6D2F1 oocytes. Because the BALB/C and B6D2F1 coat color is due to the $\mathrm{A} / \mathrm{A} \mathrm{b} / \mathrm{b} \mathrm{c} / \mathrm{c} \mathrm{D} / \mathrm{D}$ and $\mathrm{A} / \mathrm{a} \mathrm{B} / \mathrm{b} \mathrm{C} / \mathrm{C}$ D/D genotypes, respectively, the offspring are agouti (heterozygous for all loci; \#1) or brown (homozygous for the b locus; \#2). The albino mouse is their foster mother. Reproduced, with permission, from Ogonuki $\mathbf{N}$,

Mochida K, Miki H, Inoue K, Fray M, Iwaki T, Moriwaki K, Obata Y, Morozumi K, Yanagimachi R \& Ogura A 2006 Spermatozoa and spermatids retrieved from frozen reproductive organs or frozen whole bodies of male mice can produce normal offspring. PNAS 103 13098-13103 (C) 2006 The National Academy of Sciences of the USA. 
The possibility of using non-viable spermatozoa for fertilization thus represents a milestone for reproductive technology and has many potential applications that go well beyond the storage of sperm of extinct/endangered species:

1) The freezing of the whole animal (mouse) and even better the isolation and freezing of testes and epididymides are simple procedures, which can be carried out in most laboratories or even in the field. This would be a valuable precaution taken when highly valuable male animals die. Indeed, spermatozoa could easily be isolated from frozen gonads and used for inseminating oocytes to maintain the genetic line.

2) Mouse strains resistant to conventional sperm freezing might be stored by freeze-drying their spermatozoa. For instance, $\mathrm{C} 57 \mathrm{BL} / 6$ mice are commonly used as the standard mouse strain for genetic studies; however, their spermatozoa are very sensitive to freezing/ thawing (Nishizono et al. 2004). The use of freezedried spermatozoa for ICSI-assisted fertilization could overcome the problem. Moreover, the establishment of banks of frozen or better freeze-dried spermatozoa (Ward et al. 2003) would be a cost-effective approach for the storage of transgenic and mutant mouse lines, instead of continuous breeding to maintain a livestock. Lyophilized sperm might also be easily and safely transported anywhere at a very low cost (Kawase et al. 2007).

3) Non-viable spermatozoa might also be useful for producing transgenic animals. Several studies have shown that killing the spermatozoa by repeated cycles of freezing and thawing before incubation with plasmid DNA standardizes and improves the production of transgenic animals (Wu et al. 2009), probably by increasing the stickiness of the DNA vector to damaged membranes.

So far, freeze-dried spermatozoa have been used to generate embryos from a wide range of species, including mice (Wakayama \& Yanagimachi 1998), rats (Hirabayashi et al. 2005), rabbits (Liu et al. 2004), dogs (Watanabe et al. 2009), cattle (Martins et al. 2007, Abdalla et al. 2009a, 2009b), pigs (Nakai et al. 2007), primates (Sánchez-Partida et al. 2008), marsupials (Czarny et al. 2009), humans (Kusakabe et al. 2008), and fish (Poleo et al. 2005). Although most of these papers do not report the birth of animals from freezedried spermatozoa, they indicate the wide interest on alternative storage methods for spermatozoa, including human sperm (A Arav 2011, personal communication).

Freeze-drying is a powerful tool for bio-banking sperm from different species, but storing male gametes is only an unbalanced approach to preserve genetic stocks. Storing oocytes in a dry, lyophilized state appears an unlikely task at the moment; therefore, the storage of sperm cells only would offer limited advantages for the establishment of genetic banks. Somatic cells have been used as a nuclei donor for nuclear transfer, and the resulting embryos have developed into a normal individual (Wilmut et al. 1997); therefore, an alternative option might be to store lyophilized somatic cells.

\section{Reproductive technologies as a tool to test the functionality of genomes from extinct animal species and from non-viable cells: II - somatic cell nuclear transfer}

Following the demonstration of the extreme resistance of DNA in male gametes, a number of studies to address nuclear stability in somatic cells were conducted. Sheep granulosa cells and fibroblasts were exposed to physical $\left(75-90{ }^{\circ} \mathrm{C}\right.$ for $15 \mathrm{~min}-1 \mathrm{~h}$ ) or chemical stress (fixation in $100 \%$ ethanol for $24 \mathrm{~h}$ ). Both treatments resulted in the immediate loss of cell viability as demonstrated by trypan blue exclusion text. However, the nuclei of such heat-treated and fixed cells could form pronuclei after transferring into enucleated sheep oocytes, although the further fate of the reconstructed embryos was different. After transferring, nuclei from ethanol-fixed cells formed pronuclei, underwent several rounds of DNA replication without cleavage, and embryo development was arrested. Several nuclei, often with irregular shape, were found in the uncleaved oocytes ( $P$ Loi 1999, unpublished observations). Our interpretation was that critical protein component(s) of the centrosome, which is the microtubule assembly center, were irreversibly denatured by the fixative. Conversely, heat-treated donor nuclei were capable of directing early embryonic development following nuclear transfer. Altogether, these results demonstrate that the chromatin of interphase nuclei is quite resistant to physical stress.

Soon after, non-viable somatic cells were recovered postmortem from a female mouflon and injected into enucleated sheep oocytes generating, for the first time ever, a wild animal cloned from a non-viable somatic cell (Loi et al. 2001). These findings demonstrated beyond any doubt that cell viability is not related to nuclear viability, as already established in spermatozoa, and prompted further investigation on the developmental potential of nuclei from dead somatic cells.

Heat-treated granulosa cells were heated at 50 and $75{ }^{\circ} \mathrm{C}$ for 30 min before nuclear transfer in a pilot study conducted to see whether a thermal destabilization of the DNA-associated proteins improves nuclear reprogramming. Such cells were obviously killed by the heat shock, but their nuclei retained the capacity to be reprogrammed and many embryos reconstructed with these nuclei reached the blastocyst stage and developed to term (Loi et al. 2002).

Since these first reports, other work on the use of nonliving cells has been published on mice (Fulka et al. 2009), one of which of particular interest is Wakayama et al. (2008). In this study, nuclei isolated from several 
tissues, including brain, were harvested from mouse carcasses that had been frozen without any cryoprotectant and stored in a mechanical freezer at $-20{ }^{\circ} \mathrm{C}$ for 16 years. Nuclei, localized by Hoechst 33342 staining, were mechanically dissociated from the tissues and injected into enucleated oocytes. The reconstructed embryos started to cleave and healthy mice were produced. Moreover, from some blastocysts, stem cell lines were established. Paradoxically, frozen/thawed somatic cells, particularly neurons, were better 'reprogrammable' than fresh cells. Whereas fresh, viable neurons never underwent a level of nuclear reprogramming compatible with full-term embryo development, those taken from frozen bodies did, suggesting that a mild denaturation of the DNA-associated proteins might facilitate reprogramming. But the surprising finding of this study is the very long time of storage of the donor cells in a conventional freezer before nuclear transfer (Wakayama et al. 2010).

Once the suitability of non-living cells for cloning was established, the first trials to lyophilize somatic cells began. First, the same medium and conditions used for the lyophilization of spermatozoa were tested. However, enucleated oocytes reconstructed with freeze-dried cell nuclei (granulosa cells) formed irregular pronuclei, the DNA of which was evidently damaged. These findings clearly indicate that the structure of interphase somatic cells, their water content, intracellular compartments, and particularly their chromatin structure are much more vulnerable than spermatozoa to freeze-drying.

Organisms like tardigrades, which survive in the absence of water, can 'sense' the reduction of water in the environment and activate specific genes that lead to the accumulation of a simple sugar, threalose, in the cytoplasm (Crowe et al. 1985). The threalose interacts with membrane lipids and structural proteins forming a stable matrix, which protects the cells during the desiccation period (Crowe et al. 1985). On the basis of these observations, we adjusted our lyophilization protocol by adding threalose to the freezing medium. Sheep granulosa cells were thus lyophilized and stored in glass vials inside a box on the bench until use. Normal pre-implantation embryos were obtained using donor nuclei from cells lyophilized in the presence of threalose and the work culminated in the production of the first blastocysts by nuclear transfer of freeze-dried granulosa cells (Loi et al. 2008). The rate of blastocyst formation was reduced in embryos reconstructed with nuclei from freeze-dried cells, indicating the presence of some DNA damage as a consequence of the freeze-drying process. This finding was in part expected, given the radically different organization and water content of interphase somatic cells in comparison to spermatozoa. However, considering the proportion of damaged nuclei, the number of blastocysts was higher than expected, suggesting that at least part of the DNA damage was repaired by the oocyte. Besides sheep, the demonstration that lyophilized nuclei are developmentally competent once injected into enucleated oocytes has also been reported in mice (Ono et al. 2008) and pigs (Das et al. 2010).

\section{Summary and conclusions}

The possibilities offered by the use of non-living, lyophilized spermatozoa for fertilization and of lyophilized somatic cells for cloning are many and all are important.

Last year, 2010, was declared the Year of Biodiversity by the United Nations. The initiative was taken to warn about the increasing rate of species extinctions worldwide. This is both a political and a scientific issue, and although no serious measures have been implemented to cope with biodiversity loss, bio-banks of seeds and cell lines are being established in several centers. Some of them are private, but non-profitable, charitable foundations that have also started to collect and store deep-frozen tissues, cells, gametes, and embryos from thousands of endangered animals (http://www. frozenark.org). Cells are collected with the aim of using them for cloning to re-establish or expand endangered wild and/or domestic animals. They are normally stored in liquid nitrogen, a reliable and straightforward system, which, however, is very expensive in the long term. Conversely, freeze-dried cells could be stored at room temperature, which made the establishment of large genetic banks simplified and more affordable. Moreover, freeze-dried spermatozoa and cells can be shipped worldwide by mail, facilitating the exchange of mice or other (normal or transgenic) animal stocks.

The advantages of using freeze-dried cells and thus non-living genomes are clear, but there are several issues that need to be addressed before giving the green light to freeze-drying for the storage of spermatozoa and somatic cells for reproductive purposes. First of all, it is imperative to demonstrate that blastocysts derived from nuclear transfer of freeze-dried somatic cells can develop into live offspring. Secondly, with the exception of a theoretical simulation (Kawase et al. 2005), nothing is known about the long-term stability of DNA in spermatozoa and cells in the absence of water. Published reports indicate that the nuclear viability of freeze-dried cells is not lost after 5 years of storage (Loi et al. 2008) while unpublished data suggest that lyophilized cells maintain the developmental potential they showed immediately after freeze-drying even after 8 years of storage (P Loi, unpublished observations). However, as for spermatozoa, longer maintenance of the developmental potential of freeze-dried somatic cells can be realistically expected, given the organization of their nucleus. Ionizing radiations are a potential problem for their genome, but this might be conveniently avoided by properly shielding the place where such cells are stored. A third, but not less relevant, issue is the effects 
of freeze-drying on the fitness and behavior of offspring produced by ICSI or nuclear transfer of lyophilized spermatozoa/somatic cells, including long-term and trans-generational effects. The long-term effects of storing dry genomes should be assessed using suitable animal models, such as the mouse, especially for transgenerational studies.

The knowledge acquired by assessing the effects of freeze-drying on spermatozoa/somatic cells is not useful only for scientists working in the field of reproductive biology. Inspired by the demonstration that chromosomes can tolerate complete desiccation, cryobiologists challenged the conventional freezing protocols, demonstrating that human cord blood stem cells can be freeze-dried, stored, and re-activated on rehydration (Natan et al. 2009). These results were met with scepticism, for it was considered unlikely that nucleated cells could be stored lyophilized. Now the work has been successfully reproduced in a very elegant and controlled experiment, in which human hematopoietic stem and progenitor bone marrow mesenchymal cells maintained their clonogenic potential after lyophilization and 4-week storage at $25^{\circ} \mathrm{C}$ (Buchanan et al. 2010).

In conclusion, the demonstration that male gametes and somatic cells can be stored after lyophilization has tremendous potential for collecting genetic resources for the most disparate purposes such as biodiversity preservation, therapy (stem cells), farm animal breeding, and basic research. Highly valuable deceased animals, either due to their genetic background or because they belonged to endangered species, might thus be recreated using nuclear transfer, if an effective and side effect-free somatic cell nuclear transfer was available. As a proof of principle, an extinct wild goat, the bucardo, has been cloned from frozen fibroblasts isolated from skin biopsies taken from the last survivor, a female that died in 1999 (Folch et al. 2009). Certainly, there is a time limit for recreating deceased animals, which at the moment can be stored only using conventional systems. However, reproductive biologists enjoy challenges.
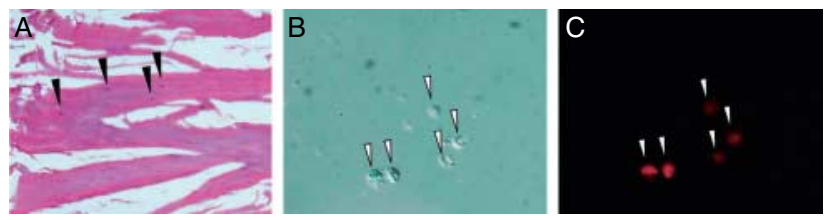

Figure 2 Appearance of nuclei in tissues of 15 000-year-old mammoth. (A) Isolated nuclei (arrowheads) in histological section of muscle stained with hematoxylin and eosin. Original magnification $\times 400$. (B) Bright field and (C) propidium iodide staining (epifluorescence). Reproduced, with permission, from Kato $\mathbf{H}$, Anzai M, Mitani T, Morita M, Nishiyama Y, Nakao A, Kondo K, Lazarev PA, Ohtani T, Shibata Y \& Iritani A 2009 Recovery of cell nuclei from 15,000 years old mammoth tissues and its injection into mouse enucleated matured oocytes. Proceedings of the Japan Academy. Series B, Physical and Biological Sciences 85 240-247. (C) 2009 The Japan Academy.
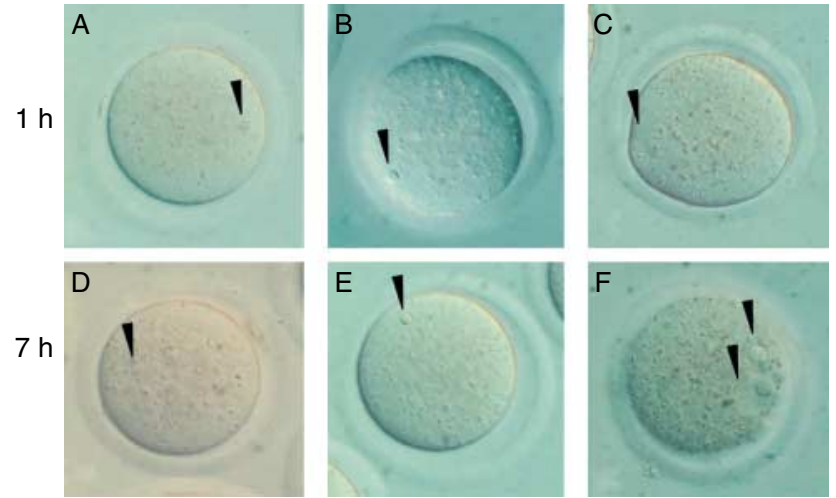

Figure 3 (A-C) Oocytes injected with nuclei derived from mammoth skin (A), mammoth muscle (B), and mouse bone marrow (C) $1 \mathrm{~h}$ after nuclear injection. Injected nuclei were visible (arrows). (D and E) Oocytes injected with nucleus derived from mammoth skin (D), mammoth muscle (E), and mouse bone marrow $(\mathrm{F}) 7 \mathrm{~h}$ after nuclear injection. In D and $\mathrm{E}$, injected nuclei without any change were still visible (arrows). Meanwhile, oocytes injected with mouse bone marrow-derived nucleus transformed into two pronuclear-like structures (arrows). Reproduced, with permission, from Kato $\mathbf{H}$, Anzai M, Mitani T, Morita M, Nishiyama Y, Nakao A, Kondo K, Lazarev PA, Ohtani T, Shibata Y \& Iritani A 2009 Recovery of cell nuclei from 15,000 years old mammoth tissues and its injection into mouse enucleated matured oocytes. Proceedings of the Japan Academy. Series B, Physical and Biological Sciences 85 240-247. (C) 2009 The Japan Academy.

This attitude finds confirmation in a paper describing preliminary procedures to clone a baby mammoth found in the Siberian permafrost (Kato et al. 2009). The first surprise of the paper is that nuclei were still retrievable from the leg tissue of a 15000 -year-old mammoth (Fig. 2); the second is that mammoth bone marrow nuclei were still able to form pronuclei (in almost $50 \%$ of the cases, Fig. 3) once injected into enucleated mouse oocytes (Kato et al. 2009). The paper does not provide further essential information, such as whether DNA synthesis did restart in the reconstructed hybrid mouse/mammoth embryos, to evaluate the functionality of the non-living genome; nonetheless, the fact that a 15000 -year-old DNA is recognized by and responds to the oocyte remodeling molecules is truly remarkable.

\section{Declaration of interest}

The authors declare that there is no conflict of interest that could be perceived as prejudicing the impartiality of this review.

\section{Funding}

Research leading to these results has received funding from the European Research Council under the European Community Seventh Framework Programme (FP7/2007-2013)/ERC grant 
agreement $n^{\circ}$ 210103; G Ptak: PRIN 2007, n² 2007MY2M92 to $G$ Ptak. P Loi acknowledges the support of the EU FP7-KBBE -2009-3 Programme, project $n^{\circ} 244356$, NextGen. J Fulka Jr is supported from MZe 0002701401.

\section{References}

Abdalla H, Hirabayashi M \& Hochi S 2009a Demethylation dynamics of the paternal genome in pronuclear-stage bovine zygotes produced by in vitro fertilization and ooplasmic injection of freeze-thawed or freeze-dried spermatozoa. Journal of Reproduction and Development 55 433-439. (doi:10.1262/jrd.20229)

Abdalla H, Hirabayashi M \& Hochi S 2009b The ability of freeze-dried bull spermatozoa to induce calcium oscillations and resumption of meiosis. Theriogenology 71 543-552. (doi:10.1016/j.theriogenology.2008.08. 021)

Asara JM, Schweitzer MH, Freimark LM, Phillips M \& Cantley LC 2007 Protein sequences from mastodon and Tyrannosaurus rex revealed by mass spectrometry. Science 316 280-285. (doi:10.1126/science. 1137614)

Buchanan SS, Pyatt DW \& Carpenter J 2010 Preservation of differentiation and clonogenic potential of human hematopoietic stem and progenitor cells during lyophilization and ambient storage. PLOS ONE 5 e12518. (doi:10.1371/journal.pone.0012518)

Crowe LM, Crowe JH, Rudolph A, Womersley C \& Appel L 1985 Preservation of freeze-dried liposomes by trehalose. Archives of Biochemistry and Biophysics 242 240-247. (doi:10.1016/00039861(85)90498-9)

Czarny NA, Harris MS, De luliis GN \& Rodger JC 2009 Acrosomal integrity, viability, and DNA damage of sperm from dasyurid marsupials after freezing or freeze drying. Theriogenology 72 817-825. (doi:10.1016/j. theriogenology.2009.05.018)

Das ZC, Gupta MK, Uhm SJ \& Lee HT 2010 Lyophilized somatic cells direct embryonic development after whole cell intracytoplasmic injection into pig oocytes. Cryobiology 61 220-224. (doi:10.1016/j.cryobiol.2010.07. 007)

Endicott P, Ho SY \& Stringer C 2010 Using genetic evidence to evaluate four palaeoanthropological hypotheses for the timing of Neanderthal and modern human origins. Journal of Human Evolution 59 87-95. (doi:10. 1016/j.jhevol.2010.04.005)

Folch J, Cocero MJ, Chesné P, Alabart JL, Domínguez V, Cognié Y, Roche A, Fernández-Arias A, Martí JI, Sánchez P et al. 2009 First birth of an animal from an extinct subspecies (Capra pyrenaica pyrenaica) by cloning. Theriogenology 71 1026-1034. (doi:10.1016/j.theriogenology. 2008.11.005)

Fulka J Jr, Loi P, Ptak G, Fulka H \& St John J 2009 Hope for the mammoth? Cloning and Stem Cells 1 1-3. (doi:10.1089/clo.2008.0052)

Goto K, Kinoshita A, Takuma Y \& Ogawa K 1990 Fertilisation of bovine oocytes by the injection of immobilised, killed spermatozoa. Veterinary Record 127 517-520.

Green RE, Malaspinas AS, Krause J, Briggs AW, Johnson PL, Uhler C, Meyer M, Good JM, Maricic T, Stenzel U et al. 2008 A complete Neanderthal mitochondrial genome sequence determined by highthroughput sequencing. Cell 134 416-426. (doi:10.1016/j.cell.2008. 06.021)

Hand SC, Menze MA, Toner M, Boswell L \& Moore D 2010 LEA proteins during water stress: not just for plants anymore. Annual Review of Physiology 73 115-134. (doi:10.1146/annurev-physiol-012110-142203)

Hirabayashi M, Kato M, Ito J \& Hochi S 2005 Viable rat offspring derived from oocytes intracytoplasmically injected with freeze-dried sperm heads. Zygote 13 79-85. (doi:10.1017/S096719940500300X)

Hoelzel AR 2005 Ancient genomes. Genome Biology 6 239. (doi:10.1186/ gb-2005-6-12-239)

Kaneko T, Whittingham DG \& Yanagimachi R 2003a Effect of $\mathrm{pH}$ value of freeze-drying solution on the chromosome integrity and developmental ability of mouse spermatozoa. Biology of Reproduction 68 136-139. (doi:10.1095/biolreprod.102.008706)
Kaneko T, Whittingham DG, Overstreet JW \& Yanagimachi R 2003b Tolerance of the mouse sperm nuclei to freeze-drying depends on their disulfide status. Biology of Reproduction 69 1859-1862. (doi:10.1095/ biolreprod.103.019729)

Katayose H, Matsuda J \& Yanagimachi R 1992 The ability of dehydrated hamster and human sperm nuclei to develop into pronuclei. Biology of Reproduction 47 277-284. (doi:10.1095/biolreprod47.2.277)

Kato H, Anzai M, Mitani T, Morita M, Nishiyama Y, Nakao A, Kondo K, Lazarev PA, Ohtani T, Shibata Y et al. 2009 Recovery of cell nuclei from 15,000 years old mammoth tissues and its injection into mouse enucleated matured oocytes. Proceedings of the Japan Academy. Series B, Physical and Biological Sciences 85 240-247. (doi:10.2183/pjab.85.240)

Kawase Y, Araya H, Kamada N, Jishage K \& Suzuki H 2005 Possibility of long-term preservation of freeze-dried mouse spermatozoa. Biology of Reproduction 72 568-573. (doi:10.1095/biolreprod.104.035279)

Kawase Y, Tachibe T, Jishage K \& Suzuki H 2007 Transportation of freezedried mouse spermatozoa under different preservation conditions. Journal of Reproduction and Development 53 1169-1174. (doi:10. 1262/jrd.19037)

Kusakabe H, Szczygiel MA, Whittingham DG \& Yanagimachi R 2001 Maintenance of genetic integrity in frozen and freeze-dried mouse spermatozoa. PNAS 98 13501-13506. (doi:10.1073/pnas.241517598)

Kusakabe H, Yanagimachi R \& Kamiguchi Y 2008 Mouse and human spermatozoa can be freeze-dried without damaging their chromosomes. Human Reproduction 23 233-239. (doi:10.1093/humrep/dem252)

Lalueza-Fox C, Römpler H, Caramelli D, Stäubert C, Catalano G, Hughes D, Rohland N, Pilli E, Longo L, Condemi S et al. 2007 A melanocortin 1 receptor allele suggests varying pigmentation among Neanderthals. Science 318 1453-1455. (doi:10.1126/science.1147417)

Liu JL, Kusakabe H, Chang CC, Suzuki H, Schmidt DW, Julian M, Pfeffer R, Bormann CL, Tian XC, Yanagimachi $\mathbf{R}$ et al. 2004 Freeze-dried sperm fertilization leads to full-term development in rabbits. Biology of Reproduction 70 1776-1781. (doi:10.1095/biolreprod.103.025957)

Loi P, Ptak G, Fulka J Jr, Cappai P \& Clinton M 2001 Genetic rescue of an endangered mammal by cross-species nuclear transfer using postmortem somatic cells. Nature Biotechnology 19 962-924. (doi:10. 1038/nbt1001-962)

Loi P, Clinton M, Barboni B, Fulka J Jr, Cappai P, Feil R, Moor RM \& Ptak G 2002 Nuclei of nonviable ovine somatic cells develop into lambs after nuclear transplantation. Biology of Reproduction 67 126-132. (doi:10. 1095/biolreprod67.1.126)

Loi P, Matsukawa K, Ptak G, Clinton M, Fulka J Jr, Nathan Y \& Arav A 2008 Freeze-dried somatic cells direct embryonic development after nuclear transfer. PLOS ONE 20 e2978. (doi:10.1371/journal.pone.0002978)

Martins CF, Báo SN, Dode MN, Correa GA \& Rumpf R 2007 Effects of freeze-drying on cytology, ultrastructure, DNA fragmentation, and fertilizing ability of bovine sperm. Theriogenology 67 1307-1315. (doi:10.1016/j.theriogenology.2007.01.015)

Miller W, Drautz DI, Ratan A, Pusey B, Qi J, Lesk AM, Tomsho LP, Packard MD, Zhao F, Sher A et al. 2008 Sequencing the nuclear genome of the extinct woolly mammoth. Nature 456 387-390. (doi:10.1038/ nature07446)

Miller W, Drautz DI, Janecka JE, Lesk AM, Ratan A, Tomsho LP, Packard M, Zhang Y, McClellan LR, Qi J et al. 2009 The mitochondrial genome sequence of the Tasmanian tiger (Thylacinus cynocephalus). Genome Research 19 213-220. (doi:10.1101/gr.082628.108)

Morozumi K \& Yanagimachi R 2006 Simultaneous removal of sperm plasma membrane and acrosome before intracytoplasmic sperm injection improves oocyte activation/embryonic development. PNAS $\mathbf{1 0 3}$ 17661-17666. (doi:10.1073/pnas.0608183103)

Morozumi K, Shikano T, Miyazaki S \& Yanagimachi R 2005 Incorporation of the acrosome into the oocyte during intracytoplasmic sperm injection could be potentially hazardous to embryo development. PNAS 102 14209-14214. (doi:10.1073/pnas.0507005102)

Nakai M, Kashiwazaki N, Takizawa A, Maedomari N, Ozawa M, Noguchi J, Kaneko H, Shino M \& Kikuchi K 2007 Effects of chelating agents during freeze-drying of boar spermatozoa on DNA fragmentation and on developmental ability in vitro and in vivo after intracytoplasmic sperm head injection. Zygote 15 15-24. (doi:10.1017/S0967199406003935)

Natan D, Nagler A \& Arav A 2009 Freeze-drying of mononuclear cells derived from umbilical cord blood followed by colony formation. PLoS ONE 4 e5240. (doi:10.1371/journal.pone.0005240) 
Nishizono H, Shioda M, Takeo T, Irie T \& Nakagata N 2004 Decrease of fertilizing ability of mouse spermatozoa after freezing and thawing is related to cellular injury. Biology of Reproduction 71 973-978. (doi:10. 1095/biolreprod.103.024422)

Ogonuki N, Mochida K, Miki H, Inoue K, Fray M, Iwaki T, Moriwaki K, Obata Y, Morozumi K, Yanagimachi R et al. 2006 Spermatozoa and spermatids retrieved from frozen reproductive organs or frozen whole bodies of male mice can produce normal offspring. PNAS 103 13098-13103. (doi:10.1073/pnas.0605755103)

Ono T, Mizutani E, Li C \& Wakayama T 2008 Nuclear transfer preserves the nuclear genome of freeze-dried mouse cells. Journal of Reproduction and Development 54 486-491. (doi:10.1262/jrd.20112)

Pask AJ, Behringer RR \& Renfree MB 2008 Resurrection of DNA function in vivo from an extinct genome. PLOS ONE 21 e2240. (doi:10.1371/journal. pone.0002240)

Poleo GA, Godke RR \& Tiersch TR 2005 Intracytoplasmic sperm injection using cryopreserved, fixed, and freeze-dried sperm in eggs of Nile tilapia. Marine Biotechnology 7 104-111. (doi:10.1007/s10126-004-0162-5)

Römpler H, Rohland N, Lalueza-Fox C, Willerslev E, Kuznetsova T, Rabeder G, Bertranpetit J, Schöneberg T \& Hofreiter M 2006 Nuclear gene indicates coat-color polymorphism in mammoths. Science 31362. (doi:10.1126/science.1128994)

Rousseaux S, Caron C, Govin J, Lestrat C, Faure AK \& Khochbin S 2005 Establishment of male-specific epigenetic information. Gene 345 139-153. (doi:10.1016/j.gene.2004.12.004)

Sallon S, Solowey E, Cohen Y, Korchinsky R, Egli M, Woodhatch I, Simchoni O \& Kislev M 2008 Germination, genetics, and growth of an ancient date seed. Science 320 1464. (doi:10.1126/science.1153600)

Sánchez-Partida LG, Simerly CR \& Ramalho-Santos J 2008 Freeze-dried primate sperm retains early reproductive potential after intracytoplasmic sperm injection. Fertility and Sterility 89 742-745. (doi:10.1016/j. fertnstert.2007.02.066)

Wakayama T \& Yanagimachi R 1998 Development of normal mice from oocytes injected with freeze-dried spermatozoa. Nature Biotechnology 16 639-641. (doi:10.1038/nbt0798-639)
Wakayama S, Ohta H, Hikichi T, Mizutani E, Iwaki T, Kanagawa O \& Wakayama T 2008 Production of healthy cloned mice from bodies frozen at -20 degrees C for 16 years. PNAS 105 17318-17322. (doi:10.1073/ pnas.0806166105)

Wakayama S, Mizutani E \& Wakayama T 2010 Production of cloned mice from somatic cells, ES cells, and frozen bodies. Methods in Enzymology 476 151-169. (doi:10.1016/S0076-6879(10)76009-2)

Ward WS \& Zalensky AO 1996 The unique, complex organization of the transcriptionally silent sperm chromatin. Critical Reviews in Eukaryotic Gene Expression 6 139-147.

Ward MA, Kaneko T, Kusakabe H, Biggers JD, Whittingham DG \& Yanagimachi R 2003 Long-term preservation of mouse spermatozoa after freeze-drying and freezing without cryoprotection. Biology of Reproduction 69 2100-2108. (doi:10.1095/biolreprod.103.020529)

Watanabe H, Asano T, Abe Y, Fukui Y \& Suzuki H 2009 Pronuclear formation of freeze-dried canine spermatozoa microinjected into mouse oocytes. Journal of Assisted Reproduction and Genetics 26 531-536. (doi:10.1007/s10815-009-9358-y)

Wilmut I, Schnieke AE, McWhir J, Kind AJ \& Campbell KH 1997 Viable offspring derived from fetal and adult mammalian cells. Nature $\mathbf{3 8 5}$ 810-813. (doi:10.1038/385810a0)

Wu Y, Liu CJ, Wan PC, Hao ZD \& Zeng SM 2009 Factors affecting the efficiency of producing porcine embryos expressing enhanced green fluorescence protein by ICSI-mediated gene transfer method. Animal Reproduction Science 113 156-166. (doi:10.1016/j.anireprosci.2008. 08.014)

Yanagimachi R 1994 Stability of the mammalian sperm nucleus. Zygote 2 383-384.

Received 2 March 2011

First decision 21 April 2011

Revised manuscript received 16 June 2011

Accepted 20 July 2011 